\title{
THE CHANGING ROLE OF THE JURY IN THE NINETEENTH CENTURY
}

MODERN discussion concerning the allocation of function between judge and jury often assumes that we are now laboring under distortions of the common law mode of jury trial introduced during the Jacksonian period. This view of jury development in the first half of the nineteenth century is clearly stated by Radin:

[I]n the several states the power of the judge became more and more restricted in the era that accompanied the rise of Andrew Jackson and the reorganized Democratic Party ... with the emphasis shifting more and more to the jury. In many jurisdictions judges were prevented from commenting on the evidence. In some, juries were made the judges of law as well as fact. ${ }^{1}$

The problems with this theory are that zeal for the jury system antedated the period of Jacksonian hegemony; that the specific changes attributed to democratic enthusiasm were not clustered in the Jacksonian decades; and that the significance of some of the changes that took place in the nineteenth century is misconstrued.

The nineteenth century was indeed a period during which the roles of judge and jury in the trial process changed greatly, but the changes which took place cannot be explained by so simple a theory. On the one hand, the jury's right to decide questions of law, a colonial heritage acknowledged earlier in the century, ${ }^{2}$ was lost. The directed verdict and the special verdict, both methods of limiting the jury's function to fact-finding, were introduced. On the other hand, attempts were made in a majority of the states to preclude trial judges from commenting on the evidence. By the end of the century, jury trial was a substantially different process from what it had been in the early days of the Republic. These procedural changes were the concrete manifestations of an underlying change, over the course of the century, in the way people conceived the purpose and competence of the jury, and its role in the process of government. Although the change in the underlying conception of the jury will be documented from more general sources, this Note will treat the specific procedural changes in Massachusetts alone. ${ }^{3}$ The modifications

1. Radin, Anglo-Aarerican Legai History 217 (1936). See also 9 Wigmoke, Evrdence § 2551, at 504 (3d ed. 1940); Hurst, The Growtri of American Law: The Law Makers 351 (1950). Dean Green's theory is somewhat different; he saw the whole of the nineteenth century as a period of "more and more domination by the jury and less and less control by the trial judge ... ." GREEN, JudGe AND JURX 379-80 (1930).

2. Howe, Juries as Judges of Criminal Lazw, 52 HARv. L. Rev. 582, $583-84$ (1939). It is useful to distinguish between the jury's right to decide questions of law and its power to do so. The jury's power to decide the law in returning a general verdict is indisputable. The debate of the nineteenth century revolved around the question of whether the jury had a legal and moral right to decide questions of law.

3. A whole range of procedural changes affecting the allocation of functions between judge and jury took place during the nineteenth century; the growth of the category of questions of law; the evolution of the rules of evidence; the development of judicial notice; 
of the jury trial in the several states differed in detail and in timetable, but the decline of the jury from its exalted status at the beginning of the century was a general trend observable in all the states. Massachusetts has been chosen chiefly because it has a relatively full body of case-law on judge-jury relations and because of the extended debates on the role of the jury in the Constitutional Convention of 1853. The developments in Massachusetts were, moreover, typical of those taking place generally throughout the United States. ${ }^{4}$ In treating changes in the general conception of the jury, arguments dealing with civil and criminal juries need not be sharply distinguished, since fundamental attitudes toward the role of the jury in both kinds of cases were similar. The civil-criminal distinction is relevant, however, in understanding specific procedural changes which affected civil juries differently from criminal juries. Due to the special social and political importance attached to the criminal jury, it retained in full force its early nineteenth century stature far longer than did the civil jury.

The popularity of the jury in eighteenth century England, where it was regarded as a check on the manipulation of the law as an instrument of royal despotism, ${ }^{5}$ was shared by the colonies with an added patriotic coloration. The colonial jury was preferred to royal judgés. ${ }^{B}$ Enthusiasm for the jury continued through the constitutional period and the first third of the nineteenth century. Indeed, one of the principal objections to the draft federal Constitution was that it failed to safeguard jury trial in civil actions. In defending this omission, Alexander Hamilton felt it necessary to assure the people of New York that no derogation of the jury's role was intended:

The friends and adversaries of the plan of the Convention, if they agree in nothing else, concur at least in the value they set upon the trial by jury. Or if there is any difference between them, it consists in this; the former regard it as a valuable safeguard to liberty, the latter represent it as the very palladium of free government. ${ }^{7}$

The rhetoric of others debating the new Constitution reflected an even greater enthusiasm for the jury: Elbridge Gerry, citing Blackstone, stated that the

and the development of the special verdict and special interrogatories. This Note concentrates on those changes which were important in Massachusetts and threw light on underlying attitudes toward the jury.

4. The jury in Massachusetts in the colonial period apparently had less authority than in the other New England states. Howe, supra note 2, at 604-05.

5. Pound, Crintralas Justice in Axrerica 115 (2d ed. 1945).

6. Ibid. An additional reason for colonial preference for the jury as opposed to the judge was the fact that many colonial judges were laymen and had no special claim to competence in the law. For instance, from 1692 to 1776 Mfassachusetts had ten chief justices and 23 associates; of these only one chief justice and two associates were lawyers. Pound, The Formative Era in Adrerican Law 92 (1938). See also 4 Andrews, Tue Colonial Pertod of Amierican History 225 (1938).

7. The Federaitst No. 83, at 456 (Scott ed. 1894) (Hamilton). Ultimately, Hamilton rests his justification of the jury's role in civil cases on the risk of corruption in judges. $I d$. at 458 . But his language reflects the high value placed on jury trial during the period. 
jury was "adapted to the investigation of truth beyond any other [system] the world can produce."s John Dickinson thought the jury a "Heaven-taught institution" and one of the "corner stones of liberty."10

Underlying the conception of the jury as a bulwark against the unjust use of governmental power were the distrust of "legal experts" and a faith in the ability of the common people. ${ }^{11}$ Upon this faith rested the prevailing political philosophy of the constitution-framing era: that popular control over, and participation in, government should be maximized. ${ }^{12}$ Thus John Adams stated that "the common people ... should have as complete a control, as decisive a negative, in every judgment of a court of judicature" as they have, through the legislature, in other decisions of government. ${ }^{13}$ Legal theory gave support to political philosophy in emphasizing the importance of the jury. The natural rights theory then current held natural justice a better source for decision than the "authority of a black-letter maxim."14 Since natural law was thought to be accessible to the ordinary man, the theory invited each juror to inquire for himself whether a particular rule of law was consonant with principles of higher law. ${ }^{15}$ This view is reflected in John Adams' statement that it would be an "absurdity" for jurors to be required to accept the judge's view of the law, "against their own opinion, judgment, and conscience."10

The importance of the jury in the judicial process in the period before 1850 is most clearly shown by the broad support given to the proposition that the

8. Gerry, Observations on the New Constitution (1788), in 2 FEderalist ANd OTnEK Constitutional Papers 714, 720 (Scott ed. 1894).

9. Dickinson, The Letter of Fabius (1788), in id. at 797.

10. Id. at 798. In a similar spirit, Justice James Wilson of the Supreme Court exclaimed, after reviewing the operation of the jury: "In criminal - in capital cases, with what sublime majesty does the trial by jury now appear to its ravished beholders!" 2 The Works of James WiLson 235 (Andrews ed. 1896).

11. Pound, op. cit. supra note 5, at 128-30 (1930); Hurst, op. cit. supra note 1, at 97; Spooner, Trial BY JURY 131 (1852) (quoted in note 63 infra).

12. Tocqueville, in his discussion of the jury's political and social functions, stressed that the jury was integral to the constellation of institutions which made the people sovereign in the United States. 1 Tocoueville, Democracy in America 280-85 (Bradley ed. 1953).

13. 2 The Works of John Adams 253 (1850) (Diary, Feb. 12, 1771). Sce also 3 The Writings of Thomas Jefrerson 81 (Washington ed. 1853) (letter to M. L'Abbe Arnold, July 19, 1789). Richard Henry Lee made a similar point, viewing the jury as a way of giving the "common people," as opposed to the judge, who would represent "the few, the well-born \&c," a voice in the administration of justice. Lee, Observations Leading to a Fair Examination of the System of Govermment, Proposed by the Late Convention (1787), in 2 Federalist and Other Constitutional Papers 867, 872 (Scott ed. 1894).

14. Shaw, Profession of the Law in the United States (1S27), 7 AM. JURIst 56, 65 (1832).

15. Pound, op. cit. supra note 5 , at 130 . It was, however, generally thought that the juror would accept rules of law as stated by the judge except in unusual cases.

16. 2 ADAMs, op. cit. supra note 13 , at 254 . 
jury should decide questions of law as well as fact in criminal cases. ${ }^{17}$ It would seem that the practice of the judges of this period of advising the jury in regard to the facts, with comments on the weight and credibility of the evidence, ${ }^{18}$ evinced a lack of confidence in the jury. But while the practice may have given the judge some control over factual determinations, it was not seen as impugning the jury's independence or competence. Rather, the jury was thought to be a partner in a joint enterprise with the judge, with respect to determinations of law and fact; judge-jury cooperation was the rule in both areas. In the words of the leading Massachusetts case, "the law presumes intelligence in the jury," so that it will not be unduly influenced by the judge's advice on the facts. ${ }^{19}$

These practices changed radically in the course of the century. An attempt was made to sharpen the law-fact dichotomy and give it concrete institutional expression. On the one hand, the jury's right to decide questions of law was denied; and the special verdict at the discretion of the judge and the directed verdict were developed to keep determinations of law from the jury. On the other hand, the judge's right to comment on the facts was closely circumscribed ${ }^{20}$ because of a growing fear of undue influence on the jury in its special sphere. These changes reflected both a loss of confidence in the ability and independence of the jury and a new view of the jury's role in the judicial process.

Judging from the limited sources available, the right of the jury to decide questions of law was widely recognized in the colonies. ${ }^{21}$ In 1771, John Adams stated unequivocally that a juror should ignore a judge's instructions on the law if it violates fundamental principles:

It is not only ... [the juror's] right, but his duty, in that case, to find the verdict according to his own best understanding, judgment, and conscience, though in direct opposition to the direction of the court. ${ }^{22}$

There is much evidence of the general acceptance of this principle in the period immediately after the Constitution was adopted. In Georgia v. Brails-

17. Howe, supra note 2, at 583-84.

18. In England, the judge in his charge advised the jury in regard to the facts. Sunderland, The Inefficiency of the Anterican Jury, 13 IIICE. L. REv. 302, 305-07 (1914);

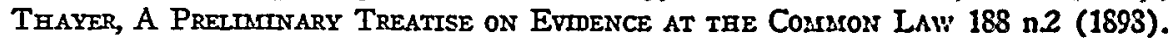
Until 1850 the judges continued to perform this function in all but seven states. Hogan, The Strangled Judge, 14 J. Axr. Jod. Soc'y 116, 119 nn.18, 19.

19. Commonwealth v. Child, 27 Mass. (10 Pick.) 252, 257 (1829).

20. By 1926, 38 states had prohibited the judge from commenting on the evidence. Hogan, stpra note 18, at 119-20 nn:18-20. Wigmore argues that the restoration of the judge's right to comment "is essential to the efficient working of the jury system." 9 WrGMORE, EVIDENCE § 2551a, at 509 (3d ed. 1940). Anachronistically, he credits the loss of the judge's right to an excess of democratic zeal in the Jacksonian period. Id. $\S 2551$, at 504 .

21. Howe, supra note 2, at 590-91.

22. 2 Aoass, op. cit. supra note 13, at 255; James Wilson took a similar view. 2 WILsoN, op. cit. supra note 10 , at 220. 
ford,,$^{23}$ a jury trial in the Supreme Court, Chief Justice Jay submitted the case to the jury on an agreed set of facts after four days of argument. In his charge to the jury, the Chief Justice noted the presumption "that the courts are the best judges of law," but stressed the jurors' "right to take upon . . . [themselves] to judge of both, and to determine the law as well as the fact in controversy."24 During the first third of the nineteenth century, other judges frequently charged juries that they were the judges of the law as well as the fact and were not bound by the judge's instructions. ${ }^{25} \mathrm{~A}$ charge that the jury had the right to consider the law had a corollary at the level of trial procedure: counsel had the right to argue the law - its interpretation and its validity - to the jury. ${ }^{26}$

In colonial Massachusetts, the right of the jury to decide questions of law was never conclusively settled, although it was recognized in a number of decisions and statutes. ${ }^{27}$ In 1808 the state legislature passed a statute giving the jury the right to "decide at their discretion, by a general verdict, both the fact and the law, involved in the issue. . . ."28 The statute was never construed by the Supreme Judicial Court up to the time of its repeal in 1836, and its effect is difficult to assess. ${ }^{30}$ There is considerable evidence, however,

23. 3 U.S. (3 Dall.) 1 (1794).

24. Id. at 4. This was a civil case; the argument that the jury had the right to decide the law in civil cases seems to have been settled against the jury in the early ninetcenth century; the debate took place later in the century over the jury's right in criminal cases. See Broeder, The Functions of the Jury: Facts or Fiction?, 21 U. CHr. L. REv. 386, 402-03 (1954); Scott, Trial by Jury and the Reform of Civil Procedure, 31 Hanv. L. REv. 669, 677-78 (1918).

The suggestion of United States v. Morris, 1 Curtis 23, 58 (Fed. Cas. No. 15,815) (D.C. Mass. 1851), cited with approval by the majority in Sparf v. United States, 156 U.S. 51, 65 (1895), that Chief Justice Jay's opinion was incorrectly reported is ably refuted by the dissenting justices in Sparf. 156 U.S. at 154-61. See also the discussion of Brailsford in Sunderland, Verdicts, General and Special, 29 YALE L.J. 253-54 (1920).

25. Howe, supra note 2, at 583-84.

26. For the Massachusetts practice, see Commonwealth v. Porter, 51 Mass. (10 Met.) 263, 284-85 (1845), discussed at notes 40-46 infra and accompanying text.

27. See Note, Powers and Rights of Juries, in QUINCY, Reports of CASES IN TIIt Juries in the Superior Court of MassachusetTs BAY: 1761-1772, 556-68 (1865 ed.). "In the Colony of Massachusetts [up to 1691], the right of the jury to determine the law was never denied in criminal cases; but was for forty years alternately recognized and disallowed in civil actions." Id. at 558.

Chief Justice Shaw noted that in Massachusetts jury trials were conducted before at least three justices throughout the eighteenth century. Hence, conflicting instructions on matters of law were often given; and the jury necessarily passed on questions of law. Shaw, $A$ Sketch of the Life and Character of the Hon. Isaac Parker, 26 Mass. (9 Pick.) $566,569-70$ (1830). The statements of John Adams, quoted in the text at note 22 supra, indicate the view of one of the leaders of the bar in 1771.

28. Mass. Laws 1807, ch. 139, $\$ 15$ (passed March 12, 1808).

29. Repealed by Mass. Laws 1836, ch. 7 .

30. In a Note, The Right of Jurors, 2 LAw REP. 187 (1839), the writer expresses satisfaction at the repeal of this "extraordinary piece of legislation." Id. at 189-90. Ho urges that the statute did no more than declare the common law right of the jury to givo 
indicating that the jury's right in both civil and criminal cases was recognized during the early part of the century. ${ }^{31}$ This can be seen in a debate in the Constitutional Convention of 1820 . A proposal was made that "in prosecutions for libels against public men, the truth may be given in evidence, and that the jury may determine both the law and the fact." 32 The proposal was defeated, in part because it was thought to do no more than "establish what was now the law of the land:"33

That the jury have the right of deciding on the law as well as the fact, is a part of the common law of the country - and it is laid down in broader and more favorable terms than in the resolution. ${ }^{34}$

A number of cases arising in the period preceding 1840 suggest that the jury's right to decide questions of law in criminal cases was generally recognized independent of the statute of 1808. In Commonwealth $2 \%$ Blanding, for example, the Supreme Judicial Court tacitly approved a charge to a jury that they need not receive the law from the judge if "they knew the law to be otherwise." 36 In the frequently cited case of Commonwealth $v$. Knapp, ${ }^{37}$ the question of the jury's right was directly confronted, but no reference was made to the statute. Defense counsel argued to the jury that they were to judge the law as well as the fact and that they should exclude defendant's confession as incompetent even though it had been admitted by the judge. Mr. Justice Putnam of the Supreme Judicial Court, sitting as a trial judge, rejected this view, instructing the jury that they had no right to pass on the admissibility

a general verdict. $I d$. at 190 . Compare Howe, supra note 2, at 606 . Due to the incompleteness of available records, it is impossible to assess the significance of the passage and repeal of this statute.

31. James Sullivan, then Attorney General of Massachusetts, stated in 1801 that the jury should pass on the constitutionality of a statute, if it is challenged in any case involving a disputed issue of fact. SULlivan, Land Trtles in MLAssacruserts 343 (1801). This suggests a recognition of the jury's right in civil as well as criminal cases. See also Coffin v. Coffin, 4 Mass. (4 Tyng) 1, 25 (1808). For other authorities recognizing the jury's right to decide questions of law in civil actions before 1808, see QuncY, op. cit. supra note 27, at 567. After 1808 the jury's right in civil cases disappeared.

In 1808 Samuel Dexter, a leader of the Massachusetts bar, was defending a client indicted in the federal court in Massachusetts under the Embargo Act. The judge instrueted the jury that the law was constitutional. In the face of repeated admonitions and the threat of contempt, Dexter argued to the jury that the act was unconstitutional. The defendant was acquitted despite the fact that he clearly had violated the terms of the statute. Dexter stated that the attorney had a moral obligation to his client to argue the hav to the jury. United States v. The William, 28 Fed. Cas. 614 (No. 16700) (D.C. Mfass. 1808); see also the account of the trial in 1 Warren, The Supreare Court in United States HistoRy 342 (1926).

32. Journal of Debates and Proceedings in the Convention of Delegates, 1820 539 (1853).

33. Id. at 540 (statement of Warren Dutton).

34. Ibid. See also statements of Isaac Parker and Charles Jackson, id. at 540, 541-42.

35. 20 Mass. (3 Pick) 304 (1825).

36. Id. at 305. The Supreme Judicial Court sustained a libel conviction but did not explicitly pass on this aspect of the charge.

37. 27 Mass. (10 Pick) 477 (1830). 
of evidence. ${ }^{38}$ But he affirmed that the jury had the "duty to decide all points of law which are involved in the general question of the guilt or innocence of the prisoner." 39

There was, then, a general acceptance of the jury's right to decide matters of law in criminal cases, although there was no clear formulation of this right. But in Commonwealth v. Porter, ${ }^{40}$ an 1845 decision, Chief Justice Shaw took a vigorous position against the criminal jury's right to decide questions of law. ${ }^{41}$ The defendant was charged with violating the state's liquor licensing statute. His attorney made several attempts to argue the inapplicability and invalidity of the law to the jury, but was cut off by the trial judge. Defense counsel excepted to these rulings and to the judge's charging the jury that it was bound to accept his statement of the law. Explicitly tying his two argum ments together, counsel conceded that he could not argue the law to the jury if the jury were bound to accept the judge's statement of the law. ${ }^{42}$ Chief Justice Shaw, however, saw them as "separate and distinct questions :"40 the jury had no right to decide questions of law in disregard of the judge's instruction but counsel could argue the law to the jury. Because defense counsel had been denied the opportunity to address legal arguments to the jury, a new trial was granted. ${ }^{44}$ Shaw argued that the constitutional guarantee of a trial before an impartial judge under standing laws would be violated if the jury were allowed to decide questions of law. ${ }^{45} \mathrm{He}$ justified permitting counsel to argue the law to the jury on the grounds that this would give the jury a clearer view of the law, which would necessarily figure in their general verdict. ${ }^{46}$ Apparently Shaw was unwilling to overrule what was concededly the

38. Id. at 495.

39. Ibid. As in Blanding, the charge contained the caution that the jury should be certain before deciding the law in opposition to the judge. But this very caution implies a recognition of the jury's right. See also Commonwealth v. Kneeland, 37 Mass. (20 Picks) 206 (1838).

A further suggestion as to the practice of the lower courts is provided by Chief Justice Shaw's opinion in Commonwealth v. Porter, 51 Mass. (10 Met.) 263 (1845). Although the court denied the jury's right to decide questions of law, it held that counsel had the right to argue law to the jury, and supported this proposition by reference to "the long practice of the courts in this Commonwealth in criminal cases." Id. at 287. It would appear that the only convincing justification for this policy is that the lawyer's argument would help the jury reach a proper conclusion in a matter of law; this gives additional support to the view that prior practice had recognized the jury's right to decide questions of law.

See also Hallett's remarks, 3 Debates and Proceedings in the State Convention to Revise and Anrend the Constitution, 1853449 (1853) [hereinafter cited as DeBATES], stating that the jury's right to decide questions of law was one "which the courts of Massachusetts always admitted to its full extent ... !"

40. 51 Mass. (10 Met.) 263 (1845).

41. This opinion was characterized by the defense counsel as "the worst reasoned judicial opinion in the Massachusetts Reports." Hallett, 3 Devates 449.

42. 51 Mass. at 274-75.

43. Id. at 275 .

44. Id. at 287.

45. Id. at 278-81.

46. Id. at 283-85. 
well-established practice in the state; but the logic of his position suffered for it.

The Porter decision aroused a great deal of opposition and its critics reopened the issue at the Massachusetts Constitutional Convention in 1853.47 The debate was so directly focused on the rule of the Porter case that Richard H. Dana accused Benjamin Hallett, who had been defense counsel in Porter; of an attempt "to make this Convention a court of errors, to rectify the decisions of the courts given in cases which he has lost."18 The convention debated and adopted a constitutional amendment designed to overrule Porter:

In all trials for criminal offenses, the jury, after having received the instruction of the court shall have the right, in their verdict of guilty or not guilty, to determine the law and the facts of the case . . . 40

47. In 1851 a coalition of Democrats and Free-Soilers, which had elected a governor in 1850, attempted to call a constitutional convention. Aforison, History of the Constitution of Massachusetts, in A Mfanual for THE Constrtutronal Conventron, 1917 1, 41 (1917). The chief impetus for the convention was dissatisfaction in the interior of the state with the system of town representation. From the beginning the project was opposed by the Whigs; in 1851, the proposal for the convention was defeated in a referendum. During the following year, the proposal was adopted, and a convention was called for the spring of 1853. Id. at 41-60. According to George S. Boutwell, a participant and former governor, this was "the ablest body of men that ever met in Mrassachusetts." Quoted in Schouler, The Massactinsetts Convention of 1853, 18 MLass. Hist. Soc. Proc. (2d ser.) 30, 33 (1903).

Professor Howe credits aggressive lawyers, seeking to exploit doubts about the constitutionality of the liquor laws, with renewing the push for jury determination of legal questions. This, of course, would give them an opportunity to argue the invalidity of the law before each jury. While this theory is plausible, the evidence to support it is tenuous indeed. See Howe, supra note 2 , at 607-10. It is Howe's thesis that the proposed constitutional amendment of 1853 and the statute of 1855 , granting the jury the right to decide questions of law (see text at note 74 infra), were political responses to the Porter decision - ways to render the liquor legislation ineffective. But the record of the debate in the DeBates suggests no such concern with the liquor legislation. Rather, the Fugitive Slave Law seemed foremost in the minds of the amendment's proponents. Sce, e.g., the remarks of Keyes, 3 Debates 443; and Allen, 3 id. at 455. Allen, in fact, stresses that "the friends of temperance" have nothing to fear from the amendment. Ibid. He also notes with satisfaction "that a large majority of the members of the Convention are of that class ...." Ibid. If a large majority of the delegates were, in fact, "iriends of temperance," the passage of this amendment suggests that they were not convinced by Hilliard's waming that "this mountainous mischief of intemperance" could never be reached by legislation if the amendment passed. Id. at 442 . Thus it seems that the impulse to reverse Porler and return to the jury the decision of questions of law must be traced to other sources.

Adlow suggests that the advocates of the jury's right to decide questions of law were aggressive lawyers motivated only by considerations of expediency. ADLow, TuE Gerrus of LeMrune SHAw 162 (1962). While there is an element of truth in this analysis, it neglects the large ideological component involved in the assertion of the jury's right as well as the long and respectable history of support for this right by people who had no personal stake. See also Lety, The Law of the Coararonwealth and Chief Justice SHAW 290 (1957).

48. 3 Debates 452 . Technically, Hallett had not lost the case, since a new trial was granted to his client. But he did lose on the important issue of the jury's right to decide questions of law.

49. Id. at 751 (appendix). The amendment was introduced by a minority of the Committee on the Bill of Rights. Id. at 430-31. It was amended before passage by the 
The debates in the convention over the jury's right to decide questions of law are remarkably articulate and complete. They present a direct confrontation between the earlier conception of the criminal jury and the newer conception represented by Porter.

Those who favored the amendment founded their case to a large extent on the notions of natural justice which had prevailed in the first half of the century. The contention that the jury had the right to decide the law really included two positions, though the sharp distinction was not always made in the debates. First, there was the view that the jury could respond to a higher law; if the statute before it was iniquitous, the jury should reach its conclusion on the basis of natural laws that were more truly just. ${ }^{50}$ In general, the amendment was taken to have this broad sweep; it was not limited to the narrower reading that the jury had the right only to interpret applicable laws. ${ }^{\text {t1 }}$ The natural law doctrine rested on the assumption that an objective standard of justice is accessible to the jury, by which it can measure the justice of the law as propounded to it by the judge. Delegates cited the Fugitive Slave Law as the kind of unjust law that a jury could deny enforcement if it had the right to appeal to a higher law.62 The codification of natural rights was thought to be the United States Constitution. Hence the reliance by the jury on a higher law was usually viewed as a constitutional judgment:

$[W]$ henever the rights which we reserve to the people are invaded by any law, I ask, that in that case, a jury coming from the people may be allowed to come in and give their judgment, and rescue the people, in the name of their declared rights, from an unconstitutional law, or from an unconstitutional interpretation of that law. ${ }^{63}$

The proponents saw "the people" as the only sure protection of the natural law standard. ${ }^{54}$ The defendant needed protection from the government; and the judge, a member of the establishment, could not be relied on to protect his rights. ${ }^{50}$ The jury's closeness to the community made it a more reliable addition of clauses explicitly recognizing the judge's right to decide questions of law arising during the trial and his right to grant a new trial in case of conviction. Id. at 499. 500,504 . These additions were meant to clarify the amendment's meaning, not to cut down the scope of the jury's asserted right.

50. Burlingame, 3 Debates 439.

51. 3 DeBates 512. Asahel Huntington, in opposing the amendment, rightly apprehended "the designs of the gentlemen who proposed it:" to permit a jury, "brought into court for the first time in their lives," to decide questions of law without being bound by previous judicial or legislative decisions.

52. See, e.g., Allen, 3 Debates 454.

53. Allen, id. at 455.

54. Burlingame, $i d$. at 439 .

55. In a book published in 1852, Lysander Spooner, a Massachusetts lawyer, defended the jury's right on the grounds that:

the justices are untrustworthy, that they are exposed to bribes, are themselves fond of power and authority, and are also the dependent and subservient creatures of the legislature.

Spooner, TRIAL BY JURY 124 (1852). Hostility to judges played a part in the impulse toward increasing the jury's role. The convention that proposed this amendment also 
guardian of the defendant's constitutional rights and a surer source of justice. ${ }^{56}$

The opponents of the amendment drew a very different picture of the jury's functioning. They pointed out that the jury was apt to be influenced by shifts of public opinion, and that the unpopular defendant would have little chance of acquittal if the jury were to decide both law and fact; public opinion, not the government, was the potentially oppressive force. 57 The judge was "of counsel for the accused," standing between the defendant and the vagaries of public opinion. ${ }^{68}$ The people were not the repository of natural justice: their opinions were more apt to reflect current prejudice. The defendant's security lay in the certainty and predictability of the law, as expounded by impartial judges. ${ }^{59}$ While they agreed that natural law underlies the legal order, the opponents focused on the positive law as a system leading to predictable results. The notion that the positive law could be set aside by any perverse juror was incompatible with their view of the law as a coherent set of principles by which men could order their lives and predict the consequences of their actions. ${ }^{60}$

The second position taken by the proponents of the amendment was that the jury is qualified to determine the contents of the positive law, using the proposed to limit the tenure of the state's justices. But the jury's right had a popular appeal independent of the hostility to the judiciary.

56. Benjamin Butler, who later earned renown as a Civil War General, reduced the argument to its essence with characteristic pungency:

Which is the best tribunal to try that case? This man who sits upon the bench, and who has no sympathy, no fellow feeling, nothing in common with the people; who has hardly seen a common man in twenty years; and lest he should see one, always has had a sheriff, with a long pole, to attend him and keep them off. Is he the better man to try the case than they who have the same stake in cormmunity, with their wives, and children, and their fortunes, depending on the integrity of the verdicts they shall render?

\section{Debates 458.}

57. Greenleaf, id. at 497.

58. Sumner, id. at 445 . Charles $R$. Train illustrated the vagaries of public opinion with this example:

I could have pointed ... to a record where the jury were judges of the law and of the fact; where, when the judge washed his hands before the multitude, saying, "I am innocent of the blood of this just person," the jury said, "Away with him I Id. at 502.

away with him! crucify him!" and that jury passed upon the law and the fact.

59. "We wish to have laws uniform and well settled, if we have laws at all." Dana, id. at 453. The centrality of these values is stressed throughout the opponents' arguments.

60. It was this view of the law which Pound spoke of:

[T] he chief energies of the courts were taken up with working out for each state a consistent, logical, minutely precise body of precedents. The task of providing rules was before their eyes to the exclusion of the task of dealing adequately with concrete causes.

Pound, Criminal Justice in Anrerica 153 (2d ed. 1945). This view of the lav underlay the "mechanical jurisprudence" of the late nineteenth century. Pound, The Fonsurtve Era of AMrrican Law 100 (1938). 
judge's instruction as evidence. This argument also had its source in a concept of natural law. The common law was thought to be relatively simple and comprehensible, closely related to principles of natural justice:

The common law is the science of reason and justice; and a man who can tell what justice is, can tell what the common law is, in almost all cases, and therefore he is just as competent to decide the case as the judge. ${ }^{01}$

It was conceded that the law in civil cases was likely to be more complex than the law in criminal cases. This distinction was used to explain the fact that the jury's right to decide the law was claimed only in criminal cases. ${ }^{02}$ It was considered essential that the criminal law should be simple, and this assumption lent strength to the position that juries should have the right to decide the law in criminal cases. ${ }^{\text {e3 }}$

Those who opposed the amendment stressed the complexity of the law, arguing that its interpretation was a matter for professionals:

Gentlemen speak of the common law as though it was perfectly easy for any man of common sense to understand all about it, without any study; but, does not every gentleman who has studied the common law as much as I have - and I have studied it considerable - know that the com-

61. Keyes, 3 Debates 443.

62. Butler, id. at 459 .

63. Ibid. Spooner argued that those who claim to have acquired a more extended knowledge of justice than is common to all ... cannot claim or expect that the whole people shall practice the folly of taking on trust their pretended superior knowledge, and of committing blindly into their hands all their own interests, liberties, and rights, to be disposed of on principles, the justness of which the people themselves cannot comprehend.

SPOONER, op. cit. supra note 55, at 131 . On the other hand, the complexity of the law governing civil matters, and to some extent criminal matters, was considered an objection to the common law as it had been imported from England. This attitude toward what the law should be was reflected in the codification movement. The confluence of the movements to reduce the law to a code comprehensible to non-lawyers and to increase the role of the jury can be seen in an 1805 pamphlet, Duane, Sampson Against tue Puilistinlis (2d ed. 1805). It urged a return to a kind of dispute settlement relying on untechuical applications of simple codified principles of law by an impartial jury. In attacking jury trial as then practiced, the author argued:

The restraints of the jury, the rules of evidence, the pleadings, the arguments of counsel, and the opinions on law, delivered by the judges, have now sunk the jury almost to an echo; to a state of degradation unbecoming freemen.

Id. at 36. In the hostility toward the common law and enthusiasm for civil law which marked the early part of the century, trial by jury, a common law institution, did not come under attack. See the arguments on codification in The Legal Mind IN AMEurca (Perry Miller ed. 1962), and Professor Miller's perceptive introductions.

The idea that the law should be a relatively simple matter was also reflected in the early nineteenth century legislation setting low requirements for admission to the bar, on the theory that the special training necessary to be a lawyer was minimal. There was a serious attempt made to deprofessionalize the practice of law. Pound, Criminal. Justice in AMrerica 49 (2d ed. 1945). 
mon law is not always common sense? . . . In the case of criminal law, who knows exactly what murder is?

Dana pointed out the poor position of the indigent defendant - with assigned counsel - prosecuted by Rufus Choate before a jury deciding both law and fact. 65 In a process that had become highly professionalized, it was incongruous to entrust the evaluation of the experts' arguments on technical points to uninformed laymen. The certainty and predictability of the system would suffer if decisions of law were left to the jury. A jury's decision on a point of law, moreover, could not be effectively reviewed by a higher court, since it would be submerged in a general verdict. ${ }^{66}$ Finally, the opponents of the amendment

64. Gray, 3 Debates 462. This argument was expanded in Chief Justice Shaw's opinion in Commonwealth v. Anthes, 71 Mass. (5 Gray) 185 (1855):

The founders of our constitution understood, what every reflecting person must understand, from the nature of the law, in its fundamental principles, and in its comprehensive details, that it is a science, requiring a long course of preparatory training, of profound study and active practice, to be expected of no one who has not dedicated his life to its pursuit....

71 Mass. at 235-36.

65. Dana, 3 Debates 508.

66. This would, of course be a matter of concern only in case of conviction, since a jury's verdict of acquittal would be unreviewable anyway. See Miller, id. at 497, 498. In their zeal to develop the importance of the law as a coherent system, those opposed to the amendment overstated the difficulty of developing the values of uniformity and predictability resulting from the jury's right to decide questions of law. They argued that a jury's determination in a matter of law could not be reviewed, since the general verdict could not be broken down into its law and fact components. Hence the law decided in a particular case could not be reviewed by a higher court. This problem, however, could have been obviated by resort to a practice, used earlier in the century, of interrogating juries. This procedure would permit a court to isolate and review the jury's determination of law, granting a new trial in case of error. In Dorr. v. Fenno, 29 1 Iass. (12 Pick.) 520 (1832), for example, the court stated:

In such cases the court will make the proper inquiries of the jury, that if it [the verdict] appear to be found upon an illegal principle or if the jury did not agree upon any ground, the verdict may be set aside.

29 Mass. (12 Pick.) at 525. This power in the trial judge, which narrowed considerably the jury's discretion under a general verdict, was apparently rarely used in the neriod before the convention, and only in civil cases; but it was available, and it was used in the following decades. See Spoor v. Spooner, 53 Mass. (12 Met) 281 (1847) ; Spurr v. Shelburne, 131 Mass. 429 (1881). The possibility of developing this procedure in criminal cases was completely overlooked. George Hillard, a distinguished lawyer, stated that "the jury may always return a general verdict, and ... they cannot be interrogated upon the grounds on which they made up their verdict. ..." 3 Debatrs 443.

The opinion in Boyden v. Moore, 5 Mass. (5 Tyng) 284 (1809), suggested an additional procedure which would permit a reviewing court to pass on decisions of law made by the jury. In reversing a verdict for defendant because of a misdirection by the judse, Chief Justice Parsons implicitly suggested the use of a presumption that the jury has conformed to the judge's instruction if the verdict is compatible with it. Conversely, if the jury's verdict is incompatible with an instruction properly stating the law, the reviewing court would set aside the jury's verdict and order a new trial. As in any case involving a new trial, the question of law would still be for the jury; but the system could be maintained in this manner, and the rules of law articulated. 
argued that the jury has no reliable way to find out what the law is, except by listening to the judge's charge. They thus challenged the natural justice assumption of the proponents. ${ }^{67}$

The argument that there should be a total separation of questions of law and questions of fact reveals a great deal about the position of those opposing the amendment; it reflects a wholly new concept of the jury's role:

... I believe that the rights of prisoners and the security of human life and liberty, under our organization of society and government, require that the powers to ascertain and declare the law should be vested in a different portion of the tribunal than that which is to ascertain the facts; the one should be the peculiar province of the court - the other the peculiar province of the jury. ${ }^{68}$

The jury was no longer seen as the "palladium of liberty" but only as an inherited device by which a court resolves questions of fact. Insofar as the jury had power to do more than determine the facts, it was a nuisance and an impediment to the attempt to reduce the law to an orderly body of rules. ${ }^{60}$

In the Convention, the amendment's opponents had conceded from the first that theirs was the unpopular side of the question, and had anticipated popular ratification. ${ }^{70}$ The Convention presented the voters of Massachusetts with a new draft constitution together with seven amendments, including the guarantee of the jury's right "to determine the law and the facts of the case" in criminal cases. The entire package was rejected by the voters in November,

67. Chandler, introducing himself as a "country farmer," asked:

Where am I to obtain that knowledge of law upon which I can rely, so as to use it without hesitation as the rule by which to judge of that man's conduct? . . . Can: I be expected to know more than the judge? Can my general information upon the subject of law, be supposed to render me capable of sitting in judgment on his opinions, and forming an idea superior to his?

3 Debates 503-04.

68. Train, 3 Debates 500-01. See also comments to the same effect by Morton, id. at 506; and Dana, id. at 508. The proponents of the bill urged that there should be no such split between law and fact. Hallett, $i d$. at 451 .

69. The jury was still thought, even by the opponents of the amendment, to have a particular competence in determining questions of fact. Marcus Morton, formerly a justice of the Supreme Judicial Court, stated:

It is their [the jury's] peculiar province to discern the facts of the case; and it is supposed, from their experience and knowledge of mankind, that they arc better qualified to determine what credit is due to witnesses, and what inferences may be drawn from circumstances, than other classes of the community - even than the judges themselves, who from the nature of their occupation, are somewhat withdrawn from society.

\section{Debates 506.}

The assumption that a clear distinction between law and fact could be made was not seriously questioned in the debates. Keyes showed a measure of sophistication in observing that a judge's refusal to permit a witness to testify after the counsel has stated whit he intends to prove will, together with the proof as outlined, have a considerable impact on the jury. 3 DeBates 513. This suggestion that a sharp law-fact distinction could not be maintained in a trial before judge and jury was not, however, developed.

70. Hillard, id. at 443 ; Dana, id. at 452. 
$1853 .{ }^{71}$ But, although the constitution and amendments were voted on separately, the voting figures 72 and the fact that there was little public debate on the amendment itself suggest that the amendment was treated as an integral part of a unit; and the reasons for the defeat of the package were unrelated to the jury trial amendment. ${ }^{73}$

Two years later, in 1855 , a statute was passed in substantially the same language as the amendment, giving the jury the right to decide matters of law and fact in criminal cases. ${ }^{74}$ The legislative victory was short-lived, however. In Commonwealth $v$. Anthes, ${ }^{75}$ decided in the year the statute was passed, Chief Justice Shaw, after reviewing the policies involved, held that the statute did no more than codify the common law, as he had articulated it in the Porter case. If the statute were interpreted to do more than restate that the jury had a right to bring a general verdict, which necessarily involves some consideration of questions of law, it was a violation of the right to jury trial and the right to be tried by standing laws before an impartial judge, guaranteed by the state Constitution. ${ }^{76}$ Thus the efforts of the 1850's, constitutional and legislative, to reaffirm the jury's right to decide questions of law ended with a judicial veto. The conceptions of the law and of the jury's role espoused by the opponents of the amendment were thus vindicated in Chief Justice Shaw's decision in Anthes.

In the years following the convention, a judicial attempt was made to separate questions of fact and law more sharply, and to restrict the jury to the former. But the succeeding decades were to see a more general assault by the courts on the utility of the jury in the trial process and a closer supervision of its role even as decider of fact.

Having established that the jury had no right to participate in determinations of law, the courts undertook to enforce the law-fact distinction in civil and criminal cases. The directed verdict as a procedural device to prevent the jury from making a determination of law was developed by the courts in Massachusetts in the same decade that the jury's right to decide questions of

71. The Constitution was defeated 68,150 to 63,222 ; the jury amendment was defeated 68,382 to 61,699 . Id. at 768 .

72. Ibid.

73. See the papers reprinted in Discussions on the Constirution Proposed to the People of Massachusetts by the Convention of 1853 (1854). Only two of the six writers discuss the amendment dealing with jury trial. For possible causes for the defeat of the package, see Miorison, supra note 47, at 63; Schouler, stpra note 47, at 41-42, 47; Lord, The Massachusetts Constitution and the Constitutional Conzentions, 2 ALsss. L.Q. 1, 26 (1916) ; Grinnell, in 4 Consmonwealte History of Massacrusetts 59-60 (Hart ed. 1930).

74. Mass. Acts \& Resolves 1855, ch. 152, at 590, now MIAss. Ges. LAws ch. 278, $\$ 11$ (1932). The bill passed the House by a vote of 202 to 106, indicating the popularity of the proposal. 1 Journal, Mass. House of Representatives 745 (1855).

75. 71 Mass. (5 Gray) 185 (1855).

76. 71 Mass. at 228-36. For a full discussion of the Anthes decision, see ADLow, The Genius of Lenruez Shaw 164-71 (1962); and Levy, The Lay of the Cososonwealtr and Chief Justice Shaw 290-95 (1957). Chief Justice Shaw used a strained 
law in criminal cases was debated and finally laid to rest. ${ }^{77}$ In Chase v. Brecd $(1855)^{78}$ Chief Justice Shaw suggested a move toward the directed verdict. A trial court judgment was reversed, and a new trial granted, on the ground that the jury could not decide the case unless properly instructed on matters of law. Chief Justice Shaw suggested, in dictum, that in some cases a trial judge should state to the jury as a matter of law whether or not it would be justified "on the whole evidence" in giving a verdict for a party. ${ }^{70}$ Commonwealth $v$. Packard, ${ }^{80}$ decided the same year, proceeded farther along the same road. Defendant was convicted on three counts of illegally selling liquor. On one of the "sales," the state offered no evidence that defendant had received compensation. The Supreme Judicial Court, holding that there could be no sale without compensation, reversed the conviction on this count and granted a new trial, with the suggestion that "there was then no evidence which ought to be left to the jury." 81

In Commonwealth v. Merrill, 82 an 1860 decision, the court held for the first time that a directed verdict is mandatory when the evidence is legally instufficient. While reversing a conviction for assault with intent to rape, the court held that the absence of evidence showing violence and felonious intent made mandatory the direction of a verdict of not guilty. The theory of the directed verdict was amplified in the same year in Gavett $v$. Manchester $\mathcal{S}$ Lazurcnce R.R. ${ }^{83} \mathrm{~A}$ verdict was directed for the defendant after it had been shown on the trial that plaintiff was injured while alighting from a moving train. In affirming the decision, the Supreme Judicial Court stated that the line between the functions of judge and jury is "certain and well-defined," 84 and it is the judge's role to pass on the legal effect of the evidence. If there is no genuine factual issue, the judge must direct a verdict, lest "the jury . . . be called on to decide a pure question of law."'85

construction of the statute to avoid declaring it unconstitutional. In view of the proximity of the convention to the passage of the legislation and the clear intent of the convention to repudiate Porter, Shaw's statutory interpretation seems disingentuous in the extreme. See dissent of Dewey, J., 71 Mass. at 237.

77. Devices existed through which the issue could be kept from the jury by the partics. At the level of pleadings, a party could demur and present the judge with an issue of law, conceding the truth of the facts as alleged by his opponent. Scott, Trial by Jury and the Reform of Civil Procedure, 31 HARv. L. Rev. 669, 678-80 (1918). Or he could demur to the other party's evidence, admitting all the facts his opponent's evidence tended to prove. This latter device, which was more akin to the directed verdict, had an important disadvantage. If the judge held against the demurring party, the verdict went for his opponent; the case was not submitted to the jury. Sunderland, Verdicts, Gcieral and Spccial, 29 Yale L.J. 253, 255-56 (1920); Scott, supra at 683-84; Thayer, A Prediminahy Treatise on the Law of Evidence at the Common Law 234-39 (1898).
78. 71 Mass. (5 Gray) 440 (1855).
79. Id. at 443 .
80. Id. at 101.
81. Id. at 103.
82. 80 Mass. (14 Gray) 415 (1860).
83. 82 Mass. (16 Gray) 501 (1860).
84. 82 Mass. at 505 .
85. Ibid. 
Thus the directed verdict was seen as a way to keep questions of law out of the hands of the jury. ${ }^{86}$ However, it also had the effect of giving the judge a role in decisions of fact. $\mathrm{He}$ was to decide whether or not there was a factual issue for the jury, which might well involve a weighing of evidence. The directed verdict went considerably beyond the judge's right to grant a new trial, which was well-established at that time. ${ }^{87}$ Declaring a new trial results in the case being retried to a new jury, whereas directing a verdict removes the case from jury consideration entirely.8 ${ }^{88}$ Thus, a device purporting to sharpen the line between the roles of judge and jury actually limited only the jury and increased the judge's participation in the area of factual determination.

Another device to limit the jury to the facts, the special verdict, while adopted in many states during the nineteenth century, was not adopted in Massachusetts. ${ }^{89}$ But the practice of interrogating juries, used in the early part of the century in Massachusetts, was revitalized in the period after 1860.00 If the jury's answers to questions put to it by the judge were inconsistent with the general verdict it had returned, a new trial would be declared. This permitted the judge to assume some control over the jury, while stopping short of those special verdict statutes which permitted the judge to enter judgment on the jury's special findings.91 The Massachusetts practice had the more limited effect of giving the matter to a new jury, rather than having the judge apply the law to the facts. ${ }^{92}$

The directed verdict and the special interrogatories were judicially developed tools to curtail the jury's power to decide questions of law. As has been seen, the Supreme Judicial Court effectively frustrated a legislative attempt to re-

86. In Denny v. Williams, 87 Mass. (5 Allen) 1 (1862), the court set out a standard for determining whether the evidence was legally insufficient and a verdict vould be directed: if the judge would set aside any number of jury verdicts as being against the weight of the evidence, he should direct a verdict. 87 MIass. at 5 . Insofar as verbal formulae affect results, this sets up a stricter standard than the standard for a new trial. But one may wonder what quantum of added certainty is necessary to set aside verdicts after the first; and whether it has any special impact to insist that a judge be sure that this additional quantum is present before a verdict is directed. In any case, the judge is clearly involved in a factual determination.

87. See, e.g., Davis v. Jenney, 42 Mfass. (1 Mfet.) 221 (1840).

88. In the twentieth century a verdict of guilty was directed in a criminal case in Massachusetts. Commonwealth v. Gardner, 241 1fass. 86, 134 N.E. 638 (1922). The case was submitted on an agreed statement of facts. In sustaining the conviction the court stated that "a question of law only was involved, and there was no error in directing a verdict of guilty on the facts agreed to." 241 Mass. at 91.

89. Thayer, A Preitainnary Treatise on Evidence at the Coasuron Law 217-19 (1898); Clemrentson, Spectal Verdicts 16, 24-43 (1905). The impulse behind the special verdict was a desire to limit the jury to a decision on the facts. It is in this sense related to the development observed in Massachusetts.

90. See cases collected in Clearentson, op. cit. supra note 89 , at 16 n.2.

91. Id. at 29.

92. No nineteenth century Massachusetts cases were found in which a general verdict was set aside because of the answers to interrogatories. 
store the jury's right to decide questions of law. Shortly after the court stated as a constitutional principle that the law is exclusively for the judge, ${ }^{08}$ legislation was passed to affect the allocation of functions between judge and jury by prohibiting the judge from commenting on the evidence. ${ }^{04}$ This legislative attempt to preserve the integrity of the jury's fact-finding function from judicial influence manifested at once confidence in the jury's ability to make factual determinations unaided and a lack of confidence in the independence of the jury - i.e., a fear of its susceptibility to influence by judicial comments. But the judiciary had still less faith in the jury, even as a fact-finding institution; it soon frustrated the legislative attempt, reasserting its right to guide the jury in reaching its conclusions of fact.

Under the common law of England at the time of independence, judges had the power to comment on the evidence and to guide the jury in its factual determination. ${ }^{95}$ This practice was followed in Commonzeralth $v$. Child (1829), a leading case in Massachusetts. ${ }^{96}$ The defendant appealed on the ground that the trial judge in his charge had:

commented upon the principal evidence in the case, and stated his opinions and inferences therefrom in diverse matters of fact ... tending upon the whole to influence the jury, by weight of his opinion, to find a verdict against the defendant. . $^{\mathrm{r}}$

The Supreme Judicial Court found this mode of charging unexceptionable. Chief Justice Parker wrote:

We know of no rule requiring the judge to conceal his opinion [about the evidence] .... [I] $f$ the evidence on one side is strong, compared with that on the other side, I think it my duty to make the jury comprehend that it is so. ${ }^{98}$

Justice Parker suggested that in cases where the judge's charge had "undue effect" on the jury, a new trial should be granted. ${ }^{00}$ But the "undue effect" concept seems never to have developed further. ${ }^{100}$

In 1858 a commission was set up to consolidate the state's statutes. In 1859 a joint legislative committee reviewed the consolidation and suggested nu-

93. Commonwealth v. Anthes, 71 Mass. (5 Gray) 185 (1855).

94. Mass. Gen. Laws ch. $231, \S 81$ (1932).

95. It is not too much to say of any period in all English History, that it is impossible to conceive of trial by jury as existing there in a form which would withhold from the jury the assistance of the court in dealing with the facts.

THAYER, op. cit. supra note 89 , at 188 n.2.

96. 27 Mass. (10 Pick.) 252 (1829).

97. Id. at 253. The trial judge denied that his charge was of this character.

98. Id. at 256.

99. Id. at 257.

100. In Curl v. Lowell, 36 Mass. (19 Pick.) 25 (1837), the court stated in dictum that although an opinion on a question of fact given by a trial judge was not open to exception, a new trial would generally be ordered if the opinion was "incorrect." 36 Mass. at 27-28. Hence the trial judge's comments were apparently subject to some kind of review, either for "undue influence" or "correctness." 
merous additions, among them a proposal that reversed the Clild rule:101 "The courts shall not charge juries with respect to matters of fact, but they may state the testimony and the law."102 Apparently the matter was not discussed widely; and the proposal was adopted with the General Statutes. ${ }^{103}$ The many similar statutes and the cases adopting a similar rule in other states were promulgated without discussion of policy or an awareness of departure from the common law. ${ }^{104}$ While speculation in such a matter is risky, it seems unlikely that such a general shift in the law occurred by chance or wholly in response to local considerations. ${ }^{105}$ More probably, the shift was due to an acceptance of the concept that the issues in a lawsuit could be clearly divided into questions of law and fact, with a corresponding division of function between judge and jury, coupled with growing doubt about the jury's independence. Disputed questions of fact were to be exclusively for the jury; if the judge were permitted to comment in his charge, his opinion would be likely to influence the jury too much.

For the time being, the courts acquiesced in this legislative determination, at least insofar as the appellate reports reveal. It had been the judiciary itself which, in Anthes, ${ }^{106}$ tried to give clear institutional expression to the law-fact distinction by sharpening the division of functions between judge and jury. The first reported decision construing the new statute was Commonwealth v.

101. The Legislative History of the Statute Relative to Charging Juries, ALAss. L.Q., November 1915, p. 76, at p. 77.

102. MASS. GEN. LAwS ch. $231, \S 81$ (1932).

103. The Legislative History of the Statute Relative to Charging Juries, IIAss. L.Q., November 1915, p. 76, at p. 77.

A story has crept into the respectable histories which credits Ben Butler, a member of the joint legislative committee in 1859, with "inducing" the committee and legislature to adopt the statute, because of his annoyance with the performance of certain judges on the bench. Grinnell, in 4 Comaronwealtr History of Miassacausetrs 67-69 (Fart ed. 1930). Although Grinnell cites no authority for the story, his reference to Justice Holmes and the late Justice Braley of the Supreme Judicial Court as its source, and similarities in the language used, suggest that it is drawn from a speech by Richard Fale on Bench and the Bar Night, in MAss. L.Q., January 1926, p. 57. Hale began by criticizing the law which prohibits judges from commenting on the evidence. He speculated that Butler was behind it, stating that Justice Holmes corroborated his suspicions. Justice Braley, after Hale had spoken, also agreed that Butler had played the vital role. (It is, of course, possible that Braley's memory, 67 years after the event, was not entircly accurate.) On the basis of this slender evidence in the Hale speech, somewhat distorted in the retelling (compare, for example, Grinnell's quote from Holmes, Grinnell, supra at 59), a historical fact was born.

An inclination to hold Butler responsible for Massachusetts legislation, otherwise unaccounted for, is also seen in Howe, supra note 2, at 609, and source cited.

104. Sunderland, The Inefficiency of the Jury System, 13 Ifrcr. L. REv. 302, 308-09 (1914). As of 1914, two-thirds of the American jurisdictions had prohibited comment by the judge.

105. For an exposition of the theory that the loss of this power vas due to local quarrels and chance considerations, see Johnson, Province of the Judge in Jury Trials, 12 J. Asr. Jud. Soc'Y 76 (1928).

106. Commonwealth v. Anthes, 71 Mass. (5 Gray) 185 (1855). 
Barry, decided in 1864.107 The Supreme Judicial Court reversed a conviction for selling liquor illegally on the ground that the judge's charge was improper. The trial judge had charged, in effect, that policemen are usually reliable witnesses, and that the jury had had opportunity to observe this in other cases. ${ }^{108}$ Chief Justice Bigelow stated alternative grounds for reversal. First, the charge suggested to the jury that they could go beyond the case as proved before them in reaching their conclusion. Second, relying on an interpretation of the new statute, he held that the credibility of witnesses is for the jury to determine. The prohibition of a charge on the facts was construed as meaning that the judge could not give his opinion about the evidence. The purpose of the statute was said to be to avoid biasing the jury's decision by having the judge's opinion "thrown into the scale in deciding upon issues of fact."10v But the court did affirm the judge's right to sum up the evidence and state its "bearing on the issues." 110

The decisions of the next few years, however, began to expand the scope of permissible comment. In Durant v. Burt (1867) ${ }^{111}$ the court gave the statute a narrower reading than it had in Barry. In a contract action, the trial judge had charged that the fact that both parties were brokers and presumed to know the usage of their trade was entitled to great weight in determining other facts. The court held that this charge did not violate the statute, and upheld the verdict, interpreting Barry as holding only that the statute prohibits comment on the credibility of testimony. The court affirmed, in general language, the judge's right - indeed his duty - "to assist and guide the deliberations of the jury" and "to lead their minds to an enlightened and discriminating consideration of the case."112

By the turn of the century, the court was giving the statute a very limited reading. The earlier decisions reflect the view that the jury was properly entrusted with the factual determination. The later cases reflect a waning enthusiasm for even that ideal, and a growing sense that law and fact cannot be isolated, and, because of the jury's limitations, should not be. The attempt to separate the roles of judge and jury by a clear law-fact distinction was a failure. The case of Whitney $v$. Wellesley \& Boston Street Ry. ${ }^{118}$ illustrates

107. 91 Mass. (9 Allen) 276 (1864).

108. Id. at 277 .

109. Id. at 279 .

110. Ibid.

111. 98 Mass. (2 Browne) 161 (1867).

112. Id. at 168.

In Commonwealth v. Larrabee, 99 Mass. (3 Browne) 413 (1868), the court followed the lead of the Burt case. In his charge to the jury, the trial judge stated that the testimony of an accomplice is suspect. The Supreme Judicial Court sustained the charge, holding that the statute prohibited comment on a particular witness, but not comment on a whole class. Although the court cited Barry as authority, it is difficult to distinguish the comment in that case on the class of policemen from the comment on the class of accomplices in Larrabee; and the Larrabee decision did not attempt to do so. 
this failure. Plaintiff claimed that her right leg had been injured when one of defendant's trolley seats fell on it. Defendant relied in part on the testimony of a doctor that plaintiff had originally complained of an injury to her left leg. In his charge to the jury, the judge cast considerable doubt on the doctor's credibility. ${ }^{114}$ Plaintiff's verdict was sustained against defendant's objection that the charge violated the statute. The Supreme Judicial Court affirmed that the judge is the "directing and controlling mind at the trial."116 $\mathrm{By}$ an sunbiased analytical statement of the facts," the judge should try to "enable jurors to see their way clear to a right verdict."116 The standards used by the court in reviewing the charge - that the judge "did not misquote the evidence"117 and that his illustrations were not "wholly inappropriate"118 — suggest a system in which the judge is expected to comment extensively on the evidence. ${ }^{119}$ The narrow interpretation given the statutory provision was further illustrated in Partelow v. Newton \& Boston Street Ry. ${ }^{120}$ The court there held that the statute prohibited only charging on the facts; commenting on the facts during the course of the trial was still permissible. Showing an uncharacteristic loyalty to legislative intent, the court disclaimed any right "to restrict the ancient power of the trial court [to comment on evidence] further than the legislature has seen fit to restrict it."121

Even more peculiar is the court's treatment of defendant's objection to the trial judge's charge that the accomplice's testimony, if believed, was corroborative. The court scemed to find the judge's conclusion correct, and rests at that. Whether or not it is correct, however, the trial judge clearly charged the jury as to an inference that might be drawn from the evidence; and this would appear to violate the statute.

In the 1870's and '80's, the court decided several cases under the statute which seem to have no unifying principle. See, e.g., Commonwealth v. Foran, 110 Afass. 179 (1872); Morrissey v. Ingram, 111 Mass. 63 (1872); Commomwealth v. Leonard, 140 Mass. 473, 4 N.E. 96 (1886). Attempting to make sense of these cases or to show their inconsistencies would be futile. However, given this kind of confusion in the state's highest court, it is easy to imagine the chaos in the trial courts and the disparate practices pursued by different trial judges.

113. 197 Mass. 495 (1908).

114. This excerpt suggests the tenor of the charge:

You have to consider whether it is a mistake on his [the doctor's] part; whether he has got some things confused there.... I don't know whether you ever saw it this term, but very often people called up as witnesses are called up and told to hold up their right hand, and they get the left hand up. I don't know how, but they get the left .... [W] [Wen you are standing opposite, face to face, and he points out where his trouble is, do you have to stop and think, make a little mental calculation, as to whether that is the left side or the right side?

Id. at 496.

115. Id. at 502 .

116. Ibid.

117. Id. at 503.

118. Ibid.

119. These standards are a considerable departure from the position of the Barry decision that the judge's opinion should not weigh in the balance.

120. 196 Mass. 24, 81 N.E. 894 (1907).

121. Id. at 34 . 
In the period following 1870 , the "diminished influence and power of juries"122 was a readily observable fact. In the case of Sparf $v$. United States (1895), ${ }^{123} 101$ years after Chief Justice Jay had charged a civil jury that it had the right to decide questions of law, ${ }^{124}$ the United States Supreme Court finally repudiated the asserted right of federal criminal juries to decide questions of law. In two opinions totalling 131 pages, all the arguments of the century were reviewed; the majority, incorporating many of Shaw's arguments in Anthes, ${ }^{125}$ emphatically rejected the old doctrine. A few states contintted to adhere to the doctrine of the jury's right in criminal cases, but this was clearly a rear-guard action. ${ }^{126}$ The period of a broad conception of the jury's role had ended. ${ }^{127}$ Those who defended the jury in this period did so in much more modest terms than had the jury's supporters in the early part of the century; they were somewhat embarrassed by the flamboyant rhetoric of the earlier period. The jury was now defended principally as the repository of "downright common sense."128

On the other hand, we don't revere it as an ancient institution of our forefathers, nor do we drop into verse over it as the "palladium of our liberties." 129

In contrast to the timorousness of the jury's defenders, attacks became increasingly more vigorous. The jury was said to be an "artificial feature" and

122. Cooke, Jury Trial Charging the Jury, 5 VA. L.J. 279, 281 (1881). Clementson interprets the special verdict statutes as emphasizing

the decline of the jury in public estimation, and hinting at its suppression, since they [juries] afford the spectacle of an arbiter who cannot exercise his functions, but who must be circumscribed and circumvented in the interest of justicc.

Clementson, Spectal Verdicts 35 (1905).

123. 156 U.S. 51 (1895).

124. Georgia v. Brailsford, 3 U.S. (3 Dall.) 1 (1794). See text at notes 23-24 supra.

125. 156 U.S. at 80-82.

126. In 1879, the Supreme Court of Pennsylvania wrote that the jury's right was "one of the most valuable securities guaranteed by the bill of rights." Kane v. Commonwealth, $89 \mathrm{~Pa} .522$ (1879). But the doctrine was quickly whittled down and finally overruled in Pennsylvania, too. Today, only Maryland and Indiana maintain the jury's right to decide questions of law. Howe, supra note 2, at 614.

127. Walker v. New Mexico \& S.P.R.R., 165 U.S. 593 (1897), manifests the extent to which the newer view of the jury had been accepted. A statute authorizing courts to require the jury to make special findings of fact, and to render judgment on the jury's findings if they conflicted with its general verdict, was challenged under the seventh amendment. The Court sustained the statute, stating that only the substance of the common law jury trial in civil cases is constitutionally protected. The Court interpreted substance very narrowly: "This requires that questions of fact in common law actions shall be settled by a jury ...." Id. at 596. After the jury finds the facts, the court can decide what verdict follows from applying the law to the facts as found by the jury. The Court thus confirmed a trial procedure which deprived the civil jury of its pozer to decide questions of law in rendering a general verdict.

128. Wilder, The Clown of the Law, 20 ALbaNy L.J. 45, 47 (1879).

129. Ibid. 
"a 'foreign body' in the system."130 Thompson analogized jury trial to an untrained crew sailing a ship, with the only navigator aboard so constrained that he can state only general principles of navigation but give no positive orders. ${ }^{131}$ For those concerned with the law as a coherent system, the jury was an inconvenience. Its vagaries were to be bypassed by the use of the directed verdict, or controlled by restricting it to fact-finding under the supervision of the judge. The values of uniformity and certainty took on paramount importance. ${ }^{132}$ And the judge, "the man learned in his ... profession," was the man who could make the system work best. ${ }^{133}$

The attack was pressed on a broader front. Thompson urged that we give "the judges more control over questions of fact at the trial, and more control over verdicts after they have been rendered."134 The policy of the mid-century that the decisional process should be split between judge and jury on a lawfact basis was much criticized and undermined.135 The realm of the judge's expertise was said to include the sifting of testimony in order to get at the truth. The argument that the judge should be permitted to comment on the evidence was taken by some to its logical conclusion. Since the judge's guidance is so useful to the jury, why not let the judge decide factual issues himself ?'136 The juror's "incompetency for the duty required of him is no longer an open question."137

The end of the century also witnessed a flood of complaints about the caliber of the people who sit on juries. ${ }^{138}$ This complaint had been a part of the history of jury trial in America; even that early jury enthusiast, James Wilson, ${ }^{139}$ had said that juries are too often composed of people who "have neither influence enough to avoid being returned, nor money enough to pay a fine for their non-attendance."140 The criticism was particularly pointed a century later, when numerous commentators began to argue that juries had "developed

130. Scott, Should Trial by Jury in Civil Cases be Abolished?, 20 A3r. L. REv. 661. 673 (1886).

131. Thompson, Charging the Jury vi (1880). Thompson was the chicf editor of the AMIERICAN LAW REVIEW and the author of numerous books on trial practice and other subjects. 18 Dictionary of AdIERICAN BIograpHy 471 (1936).

132. See, e.g., Wade, Jurors as Judges in Criminal Cases, 3 Crass. L. MLaG. 484, 491 (1882).

133. Ibid.

134. THosrpson, op. cit. supra note 131 , at iv.

135. Thayer, for example, cast doubt on the reality of the law-fact split in jury trials. Thayer, "Law and Fact" in Jury Trials, 4 HARv. L. REv. 147 (1890).

136. Scott, supra note 77, at 670 .

137. Id. at 668 .

138. See, e.g., Campbell, Some Hints on Defects in the Jury System, 4 Souruens L. REv. (n.s.) 521 (1878). Another commentator wrote that it was "exceptional" to see "a tolerable amount of intelligence and competency in the jury box." Whitchouse, Trial by Jury, As It Is and As It Should Be, 31 AlBaNy L.J. 504, 506 (1885).

139. See note 10 supra.

140. 2 The Works of Jantes Wilson 205 (Andrews ed. 1896). 
agrarian tendencies of an alarming character;"111 and that damage suits invariably went in favor of individuals and against corporations. Many influential members of the bar evidently objected to the jury because it would be hostile to their clients and sympathetic to poor litigants. Francis Wharton extended the argument to criminal cases. After describing the risks of partiality in juries, he noted that the decisive issues of the future will not be race or party, but "those which involve the relations of capital to labor, of corporations to the public."142 $\mathrm{He}$ foresaw the possibility that juries, if they had the right to decide law as well as fact, might convict corporate officers and directors of attempting to monopolize the goods of the community.

At the end of the nineteenth century the rhetoric of the jury's critics reflected the decreased importance of the jury in the trial process and in legal and political theory. The concept of a natural law accessible to the common man was alien to lawyers and judges who distrusted the common man, and who thought of the law as a set of positive rules leading to predictable results. The jury at the outset of the century had been regarded as a mainstay of liberty and an integral part of democratic government. But by the end of the century the jury had come to be seen as an outmoded and none-too-reliable institution for resolving disputed questions of fact.

141. Thompson, op. cit. supra note 131, at iv; see also Whitehouse, supra note 138, at 506; Clementson, Spectar Verdicts 34.

142. Wharton, 36 LEGAL INTELLIGENCER 405, 406 (1879), reprinting article from SoutHern L. Rev., Aug.-Sept. 1879. Wharton, the author of a standard treatise, was a leading expert on criminal law in the nineteenth century. 